\title{
БОРЬБА ВОЗ С ФАРМАЦЕВТИЧЕСКИМ КОНТРАФАКТОМ: СООТНОШЕНИЕ ЗАЩИТЫ ЗДОРОВЬЯ НАСЕЛЕНИЯ И ЗАЩИТЫ ПРАВ ИНТЕЛЛЕКТУАЛЬНОЙ СОБСТВЕННОСТИ
}

\begin{abstract}
Аннотация. Статья посвящена исследованию деятельности ВОЗ в сфере противодействия фармаиевтическому контрафакту в аспекте развития данной организацией понятия «контрафакт». Автор последовательно прослеживает работу ВОЗ по уточнению своей компетенции в сфере обеспечения доступа к качественным и эффективным лекарственным препаратам и показывает, что защита прав интеллектуальной собственности является смежным вопросом, который не входит в круг ее деятельности. В статье обосновывается, что точные формулировки понятия «фармацевтический контрафакт» являются условием эффективности международного сотрудничества по противодействию напльву подделок, создающих угрозу жизни и здоровью населения. Особое внимание уделяется анализу сопряженности деятельности ВОЗ по координации международных усилий по противодействию фармацевтическому контрафакту и закреплению за понятием «контрафакт» смысла «подделка» без коннотации «нарушение прав интеллектуальной собственности». В своей статье автор опирается на сравнительный анализ подходов к определению понятия фармацевтический контрафакт в национальном и международном праве. Помимо этого в качестве предмета сравнения выступают подходы к проблеме соотношения зашиты здоровья населения и защиты прав интеллектуальной собственности, высказываемые ВОЗ и ВОИС. Это позволяет обосновать существование на уровне международного сотрудничества двух стратегий по отношению к противодействию фальшивой фармачевтической продукции. Научная новизна статьи заключается в выявлении на примере деятельности ВОЗ как авторитетной международной организации природы соотношения между правами человека в сфере здравоохранения и правами интеллектуальной собственности. Автор приходит к выводу о том, что ни одна из специализированных международных организачий не может одновременно бороться с фальсификацией фармацевтической продукции в аспекте защиты права на доступ к качественным и эффективным лекарственным средствам и в аспекте защиты прав интеллектуальной собственности. Однако различные международные организачии, работающие в данной сфере, должны в обязательном порядке учитывать указанные аспекты. В качестве основы особенности подхода ВОЗ автор выделяет тот факт, что защита прав человека выступает приоритетом по сравнению с защитой прав интеллектуальной собственности, которые не относятся к категории международно признанных прав человека. Ключевые слова: доступ клекарствам, медицинский фальсификат, интеллектуальная собственность, права человека, международное сотрудничество, глобализачия, патенты, товарные знаки, общественное здравоохранение, Всемирная организачия здравоохранения

Abstract: The article is devoted to the study of the activities of the WHO in the sphere of fighting pharmaceutical counterfeit in the aspect of development of the term "counterfeit" by this organization. The author consequently follows the work of the WHO on clarification of its competence in the sphere of guaranteeing access to quality and efficient medications, showing that protection of intellectual property rights is a related issue, while being outside the scope of its activities. The article substantiates the position that clear formulae of the term "pharmaceutical counterfeit" are necessary for efficient international cooperation in the sphere of fighting against the wave of counterfeit medications, them being a threat to life and health of the people. Special attention is paid to the correlation between the WHO activities on coordination of international efforts against pharmaceutical counterfeit, and defining "counterfeit" as a "fake" without connotation to the "violation of intellectual property rights". In this article the author bases his studies upon the comparative analysis of the approaches to defining pharmaceutical counterfeit in national and international law. In addition, for
\end{abstract}


the comparative purposes the author uses the approaches towards correlation between protection of health of the population and intellectual property protection in the WHO and the WIPO. It allows for the substantiation of the existence of two international cooperation strategies regarding fighting fake pharmaceutical products. The scientific novelty of the article is due to revealing the nature of correlation between human rights in the sphere of healthcare and intellectual property rights based upon the example of the activities of the WHO, it being an authoritative international organization. The author makes a conclusion that none of specialized international organization is capable of simultaneously fighting falsification of pharmaceutical products in the aspect of protection of right to access to quality and efficient medication and in the intellectual property protection aspect. However, different international organizations in this sphere should take these aspects into consideration. As the basis for the specific features to the WHO approach, the author points out the fact that protection of human rights has higher priority than intellectual property protection, since intellectual property rights are not basic human rights.

Keywords: access to medication, medical counterfeit, intellectual property, human rights, international cooperation, globalization, patent, trademark, public healthcare, the World Health Organization.

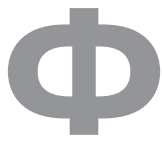

альсифицированная и контрафактная продукция, ее производство, реклама и реализация, начиная от подделок в сфере культурных ценностей и заканчивая подделкой игрушек, стала глобальной проблемой. Особую обеспокоенность государства, международные межправительственные и неправительственные организации, ассоциации производителей, общественность высказывают в отношении глобализирующегося оборота фальсифицированной медицинской продукции (медикаментов и медицинских изделий), который затронул не только развитые, но и, в особенности, развивающиеся страны ${ }^{1}$. Высоко поднявшаяся волна потоков поддельной медицинской продукции, составляющая почти $10 \%$ мировой торговли и увеличивающейся почти на $20 \%$ ежегодно.

Экономические последствия и последствия фармацевтического контрафакта в сфере общественного здравоохранения сегодня устойчиво рассматриваются в качестве связанных аспектов ${ }^{2}$. От производителей контрафакта несут финансовые и имиджевые потери законные производители, а также сами потребители, осознано или неосознанно приобретающие более дешевую - контрафактную - продукцию, способную причинить вред их здоровью и благополучию.

\footnotetext{
${ }^{1}$ Putze E., Conway E., Reilly M., Madrid O. The Deadly World of Fake Drugs (2012)//http://www.aei.org/files/2012/02/27_appendix_a-master-2-170026856632.pdf (дата обращения: 15.01.2014 г.).

${ }^{2}$ Chika A., Bello S.O., Jimoch A.O., Umar M.T. The Menace of Fake Drugs: Consequences, Causes and possible Solutions // Research Journal of Medical Sciences. 2011. Vol. 5. Issue 5. P. 258.
}

Поэтому мировое сообщество исходит из того, что подделка, а равным образом деятельность по ее производству и реализации далеко не безобидная вещь. Конкретизацией комплексной проблемы контрафакта является связь вопросов общественного здравоохранения и вопросов защиты и соблюдения прав интеллектуальной собственности ${ }^{3}$.

Поскольку главной международной организацией, координирующей международные усилия в сфере противодействия обороту фальсифицированной медицинской продукции выступает Всемирная организация здравоохранения (далее - ВОЗ), повышенной актуальностью отличается вопрос о подходе данной организации к соотношению защиты здоровья населения защиты прав интеллектуальной собственности в процессе данного противодействия. Представляется, что именно от выбора правильной композиции предпринимаемых усилий во многом зависит успех в деле противостояния данной глобальной угрозе.

1.Международное сотрудничество в срере противодействия фармацевтическому контрафакту: основные инициативы. Прежде чем характеризовать особенность подхода ВО3 к соотношению защиты здоровья населения и защиты прав интеллектуальной собственности (далее - ИС) в борьбе с фальсификацией фармацевтической продукции необходимо вкратце

\footnotetext{
${ }^{3}$ Davison $M$. Pharmaceutical Anti-Counterfeiting Combating the Real Danger from Fake Drugs. New Jersey: Wiley, 2011. P. $73-$ 80; Bate R. Fake: The Deadly World of Falsified and Substandard Medicines. Washington: AEI Press, 2012. P. 387 -395.
} 
охарактеризовать общее состояние международного сотрудничества в данной сфере. Если говорить о позиции развивающихся стран, то они заинтересованы главным образом в защите здоровья населения. Это вызвано тем, что по подсчетам ВОЗ в некоторых развивающихся странах фальсифицированная фармацевтическая продукции составляет до $60 \%$ отдельных категорий лекарственных средств, которые в лучшем случае неэффективны, а в худшем - опасны. На этом фоне защита интересов правообладателей для них не столь актуальна, поскольку данная группа стран только еще находится в процессе становления законодательства в данной сфере и соответствующих институтов.

Противодействие фальсификации медицинской продукции в целом и фармацевтической продукции в частности в рамках общей стратегии противодействия интеллектуальному пиратству и контрафакту является предметом прямой заинтересованности развитых государств. Большой интерес представляет анализ экономических последствий контрафакции и пиратства, проведенный $\mathrm{OЭCP}^{4}$. Заметным актором в сфере противодействия поддельной и контрафактной продукции выступает такая квазимеждународная организация, как Большая восьмерка (G8), в последнее время уделяющая повышенное внимание защите прав ИС.

Разумеется, для успешного исхода противодействию фармацевтическому фальсификату, необходимо знать - с чем бороться. Поэтому в настоящее время выработана классификация поддельных лекарственных средств. Все поддельные лекарства являются опасными для жизни и здоровья в виду отсутствия контроля их качества со стороны регулирующих органов. На сегодняшний день можно выделить несколько видов фальсификации - отличная имитация (копия) активного вещества и упаковки известного товарного знака; имитация препаратов, не содержащая активное вещество или содержащая его недостаточное количество; имитация препаратов, содержащих другое активное вещество, которое не соответствует маркировке; препараты, содержащие

\footnotetext{
${ }^{4}$ OECD. The Economic Impact of Counterfeiting and Piracy. Directorate for Science, Technology and Industry, Committee on Industry, Innovation and Enterpreneurship. Paris: OECD Publishing, 2008.
}

вредные токсические вещества ${ }^{5}$ В последнее время актуализируется вопрос о фальсифицированных недоброкачественных субстанциях, из которых изготавливают лекарственные средства. По оценке ВО3 наиболее подделываемыми являются антибиотики (например, амоксициллин), противотуберкулезные, противомалярийные и антиретровирусные препараты. Если говорить о развитых странах, то здесь наиболее часто подделываются препараты, оказывающие влияние на стиль жизни (силденафил, анаболические стероиды психотропные средства и т.д.).

Общепризнанно, что фальсификация медицинской продукции несет с собой не только угрозу отдельным пациентам, но и всей системе общественного здравоохранения, подрывает доверие к ней. В частности, использование поддельных лекарственных средств приводит к неполучению должного лечения, а в ряде случаев - к летальному исходу. По мнению Совета Европы, «фальсификация продукции медицинского назначения и сходные преступления - это молчаливые убийцы, ибо неэффективность лечения и есть болезнь, от которой умирает больной» ${ }^{6}$.

Производство подделок, будучи известным с древних времен, поставлено сегодня на поток. Под влиянием НТП и делокализацией производства в условиях глобализации, а также недостаточно высокой защиты прав интеллектуальной собственности в ряде стран, особенно развивающихся, деятельность по производству контрафакта из маргинальной превратилась в хорошо организованный и прибыльный бизнес, связанный с организованной преступностью. В свете сказанного противодействие фальсификации медицинской продукции в настоящее время рассматривается в качестве вопроса не только национальной, но и международной безопасности 7 . Поэтому ответом

\footnotetext{
${ }^{5}$ Ушкалова E.A. Проблемы фальсификации лекарственных средств: фокус на антимикробные препараты // Клиническая микробиология и антимикробная химиотерапия. 2005. Т. 7. № 2. C. 169.

${ }^{6}$ Совет Европы. Конвенция Медикрим. Противодействие фальсификации изделий медицинского назначения и сходным преступлениям. Страсбург: Европейский директорат по качеству лекарственных средств, 2011. С. 4.

${ }^{7}$ Wertheimer A., Wang P. (eds) Counterfeit medicines. Vol. I. Policy, Economics and Countermeasures. Glendale: ILM Publications, 2012.
} 
на этот вызов стали меры по повышению уровня эффективности международного сотрудничества по противодействию контрафакту на основе различных международных программ под эгидой универсальных и региональных международных организаций, включая Совет Европы (далее-CE).

К одному из наиболее значимых событий в рамках предпринимаемой не только на региональном международном, но и универсальном международном уровне борьбе с контрафактной продукцией в области уголовных мер стало принятие в 2010 году Конвенции Совета Европы о борьбе с фальсификацией медицинской продукции и сходными преступлениями, угрожающими здоровью населения, или конвенции Медикрим ${ }^{8}$. Значение конвенции заключается в направленности на достижение максимальной гармонизации законодательства разных стран в сфере противодействия фальсификации медицинской продукции. Церемония подписания Конвенции прошла 28 октября 2011 года в Москве и была приурочена к Международной конференции высокого уровня «Противодействие распространению контрафактной медицинской продукции» (26-28 октября 2011 года), прошедшей под эгидой $\mathrm{CE}^{9}$. Это первое международное соглашение в области уголовного права, выступающее инструментом противодействия фальсификации медицинской продукции, угрожающей здоровью населения. Идея подготовки Конвенции была высказана в 2006 году в период председательства России в Комитете министров СЕ. Работа над проектом документа осуществлялась в 2007 - 2009 гг. в экспертных кругах СЕ. 8 декабря 2010 г. Комитет министров одобрил проект конвенции и предложил Генеральному секретарю СЕ направить ее странам, которые не являются членами СЕ, но заинтересованным в присоединении к конвенции.

Особенность данной конвенции состоит в том, что термин «фальсификация» соответствует

\footnotetext{
${ }^{8}$ Council of Europe Convention on the counterfeiting of medical products and similar crimes involving threats to public health (Moscow, 28.X.2011) (CDCE № 211) http://www.conventions.coe.int/ Treaty/EN/Treaties/Html/211.htm (дата обращения: 1.02.2014 г.).

${ }^{9}$ Более подробно см.: Островский А.Н., Новокрещенов И.В., Новокрещенова И.Г., Аранович Л.М., Морозов В.П. Конвенция «Медикрим»: противодействие фальсификации медицинской продукции в области уголовного права // Вестник Росздравнадзора. 2011. № 6. С. 4 - 8 .
}

в ней понятию «подделка», но без коннотаций с правами ИС. Поэтому конвенция направлена не на противодействие медицинскому контрафакту в том смысле, который сегодня закрепился за термином «контрафакт», а на противодействие медицинскому фальсификату с точки зрения защиты здоровья населения и общественной системы здравоохранения.

Вместе с тем, надо признать, что принятие конвенции по уголовным мерам предупреждения и пресечения фальсификации медицинской продукции и сходным преступлениям не означает, что организация занимается исключительно только этими аспектами в решении проблемы. $\mathrm{CE}$ - многопрофильная организация, поэтому для нее характере комплексный подход к оценке контрафакта - как с точки зрения последствий для индивидуального и личного здоровья, так и с точки зрения необходимости зашиты прав ИС.

На сегодняшний день вопросам противодействия медицинскому фальсификату, прежде всего фармацевтическому фальсификату, уделяют внимание международные универсальные организации - ВО3, ВТО, Всемирная таможенная организация, ВОИС, Интерпол, а также другие международные правительственные и неправительственные организации ${ }^{10}$. В последнее время к проблеме контрафактных лекарственных средств обратился Всемирный Банк, который совместно с ВОЗ провел, Глобальный форум по праву, правосудию и развитию, посвященный возможным решениям в сфере противодействия контрафактной лекарственной продукции (Вашингтон, 2 - 3 октября 2012 года) ${ }^{11}$.

Если говорить о Международной торговой палате (International Chamber of Commerce (ICC), то при ней функционирует Бюро расследования

\footnotetext{
${ }^{10}$ Терехов А.Ю. Актуальные вопросы международно-правового регулирования предотвращения оборота фальсифицированных лекарственных средств в рамках межправительственных организаций // Евразийский юридический журнал. 2011. № 4. C. 27; См. также: WHO. Counterfeit medical products. Report by the Secretariat, para. 7. A/62/13 (30 April 2009) // http://www. coe.int/t/dghl/standardsetting/medicrime/WHA\%20A62_13-en.pdf (дата обращения: 4.04.2014 г.).

${ }^{11}$ Counterfeit Medicines. Impact and Potential Solutions (2 - 3 October, 2012)// http://globalforum.ljd/does/events/1002212_couterfeit/ presentations/Deats_Globalhealthperspective.pdf (дата обращения: 15.01.2014 г.).
} 
фальсификации, в состав которого входят фармацевтические компании, разработчики стандартов, эксперты в области технологии борьбы с данным явлением, а также представители национальных правоохранительных органов. Бюро позволяет обмениваться информацией на международном уровне, а также оказывает консультативные услуги по методам производства продукции, которая с трудом поддается копированию. В дополнении к этому Бюро собирает информацию о фальсифицированной продукции, проводит самостоятельные расследования, разрабатывает учебные программы и т.д.

Международной организацией, специально занимающейся координацией международного сотрудничества в сфере противодействия медицинскому контрафакту, выступает ВОЗ. Координацию международных усилий в этом направлении осуществляют на самостоятельной, но взаимосвязанной основе - Секретариат, Целевая Группа против контрафактной медицинской продукции (IMPACT), Рабочая группа ВО3 по некондиционной/поддельной/ложно маркированной/фальсифицированной/контрафактной медицинской продукции, Целевая группа по осуществлению регулирования и т.д. Помимо этого организация осуществляет сотрудничество с государствами и заинтересованными организациями на региональном уровне (Африка, Америка, Восточное Средиземноморье, Европа, Юго-Восточная Азия, Тихоокеанском регионе) ${ }^{12}$.

Впервые на международном уровне с участием ВОЗ проблема фальсифицированной и контрафактной лекарственной продукции стала обсуждаться в связи с рекомендациями Международной конференции экспертов по рациональному использованию лекарственных средств (Найроби, 25 - 29 ноября 1985). Результатом работы данной конференции стало признание противодействия фальсификации лекарственных средств важнейшим направлением деятельности ВОЗ, которая вместе с другими международными правительственными и неправительственными организаци-

\footnotetext{
${ }^{12}$ См.: ВОЗ. 63-я сессия Всемирной ассамблеи здравоохранения. Пункт 11.20 предварительной повестки дня. Контрафактная медицинская продукция. Доклад Секретариата. A63/23 (22 Апреля 2010 г.) // http://apps.who.int/gb/ebwha/pdf_files/ WHA63/A63_23-ru.pdf (дата обращения: 13.03.2014 г.).
}

ями учредила информационный центр, призванный собирать данные о характере и масштабах контрафактной активности и информирующий об этом правительства.

В докладе конференции подчеркивалось, что правительства должны принять меры, которые необходимы для предупреждения подделки лекарственных средств, рассматриваемой некоторыми участниками как преступное деяние, с которым должны по мере возможности бороться все органы по регулированию обращения лекарственных средств. В этой связи ВОЗ вместе с другими международными правительственными и неправительственными организациями было рекомендовано изучить практическую осуществимость создания информационного центра по сбору данных и проинформировать правительства о характере и масштабах подделки, в том числе в целях борьбы с уголовными правонарушениями, в качеств которых выступает подделка лекарственных средств ${ }^{13}$.

Далее в 1988 году в соответствии с резолюцией Ассамблеи здравоохранения WHA41.16 Генеральному директору ВОЗ было предложено в сотрудничестве с Генеральным секретарем ООН предпринять шаги по осуществлению программ предупреждения оборота контрафактной лекарственной продукции, нарушающего международные договоры о лекарствах. В результате начиная с этой резолюции ВОЗ в своих документах и других резолюциях, например, Резолюции WHA47.13 о рациональном использовании лекарственных средств, Программе действий ВОЗ по основным лекарственным средствам, резолюции WHA52.19 о пересмотренной стратегии в области лекарственных средств, в Руководящих принципах по надлежащей практике распространения фармацевтических препаратов стал использовать термин «контрафактные лекарственные средства».

В качестве продолжения указанных инициатив стало проведение $1-3$ апреля 1992 года в Женеве семинара, организованного ВОЗ и Международной федерацией производителей и ассоциаций фармацевтической продукции.

\footnotetext{
${ }^{13}$ The rational use of drugs. Report of the Conference of Experts (Nairobi, 25 - 29 November 1985). Geneva: WHO, 1987. P. 8 // http://apps.who.int/medicinedocs/documents/s17054e/s17054e.pdf (дата обращения: 15.01.2014 г.).
} 
Значение данного семинара заключается в том, чтобы на нем было согласовано определение «контрафактных лекарственных средств». Согласно этому определению, контрафактным является лекарственное средство, имеющее предумышленную и обманную маркировку, ложную о том, что касается наименования и/или источника происхождения лекарственного средства. Контрафакт может применяться как к брендовым изделиям, так и к дженерикам. Контрафактные изделия могут включать в себя продукцию с правильными ингредиентами или с неправильными ингредиентами, без активных ингредиентов, с недостаточным количеством активного ингредиента или с фальсифицированной упаковкой ${ }^{14}$.

Анализируя определение можно заметить, что в него помимо родовых критериев контрафакта включаются его виды. Это определение имело важное значение, так как данное понятие по-разному интерпретируется в различных государствах, что не только затрудняет обмен информацией, но и международное сотрудничество по предупреждению и пресечению оборота данной продукции. Дело в том, что ясное определение является важным средством для четкого понимания проблемных вопросов.

В дальнейшем в поле внимания ВО3 оказалась проблема некачественных медикаментов. В результате организация стала использовать собирательное понятие «некондиционная/поддельная/ложно маркированная/фальсифицированная/контрафактная медицинская продукция», которое, однако, не рассматривается ВОЗ как синоним понятия «контрафакт». Некачественная и контрафактная продукция различны по своей природе: контрафактная продукция не является лекарственной продукцией, поэтому не может быть подведена под понятие «некачественная медицинская продукция». Тем не менее ВОЗ отдает себе отчет в том, что понятие «контрафактные лекарственные средства» является достаточно абстрактным понятием, что показывает сохранение проблемы выработки определения, согласованного на международном уровне. Условность этого

\footnotetext{
${ }^{14}$ WHO: General Information on counterfeit medicines // http:// www.who.int/medicines/services/counterfeit/overview/en (дата обращения: 15.01.2014 г.).
}

термина демонстрирует факт его «заковыченного» использования в документах ВОЗ.

ВО3, осознавая всю значимость проблемы, стала организационным центром не только сбору информации, но и по организации по осуществлению обзора противодействия данному негативному явлению во всем мире. Достаточно крупный обзор был представлен на совещании, которое предшествовало 11-й Международной конференции органов, регулирующих лекарственные средства (Мадрид, 16 - 19 февраля 2004 года).

ВОЗ придает противодействию медицинскому контрафакту особое значение, так как контрафакт выступает одной из помех для доступа к качественным и недорогим лекарствам. В силу этого в рамках организации в 2004 - 2006 гг. обсуждалась возможность принятия концептуального документа по международной конвенции о контрафактной медицинской продукции. Однако Мадридское совещание 2004 года показало отсутствие консенсуса между государствами в лице их органов, регулирующих оборот медицинской продукции.

Неудачу по разработке концептуальной основы будущей конвенции компенсировала чрезвычайно важная инициатива по созданию в 2006 году Международной Целевой группы по борьбе с медицинской контрафактной продукцией (International Medical Products AntiCounterfeiting Taskforce /IMPACT), в деятельности которой принимает участие СЕ. Она была учреждена после проведения международной конференции ВО3 по вопросам контрафактной медицинской продукции «Борьба с контрафактными лекарственными средствами: налаживание эффективного международного сотрудничества» (Рим, 16 - 18 февраля 2006 года), или Римской конференции. В Римской декларации, которая была принята 160 участниками конференции, содержался призыв к ВОЗ возглавить работу по созданию Международной целевой группы по борьбе с контрафактной медицинской продукцией. Декларация также включает ряд принципов, а также концептуальную основу работы Целевой группы по обеспечению соблюдения интересов общественного здравоохранения. Группа была создана в короткие сроки. Поэтому уже спустя два месяца 12-я Международная конференция органов по регулированию обращения лекарственных 
средств (Сеул, 3 - 6 апреля 2006 года) приветствовала создание Группы. Целевая Группа в сотрудничестве с более чем двадцатью различными международными партнерами осуществляет выработку предложений и рекомендаций в формате государственно-частного партнерства по вопросам законодательства и правоприменения, торговли, инноваций, технических мер, связанных с обнаружением подделок. Целевая группа включает в себя пять рабочих групп по разным направлениям, например, законодательству, технологиям, коммуникации и т.д.

Однако несмотря на то, что вопросами борьбы с контрафактом уделяют многие международные структуры, их деятельность не всегда скоординирована. Одним из показателей недостаточной координации является отсутствие полной статистики оборота контрафактной медицинской продукции и причиненном ей ущербе. Поэтому в настоящее время ставится вопрос о создании Международного координационного центра. К тому же сохраняющиеся различия в национальных законодательствах в отношении предупреждения и пресечения данных правонарушений не соответствует реалиям глобализации и транснационализации медицинского контрафакта. В этих условиях ни одно из государств не может быть застраховано от массового наплыва подделок, зачастую неконтролируемо распространяемых через Интернет, половина реализуемых фармацевтических препаратов через который являются фальсифицированными. Однако можно выделить ряд государств, такие как США и Японию, где с помощью принятия специальных законов данный вид преступной деятельности пресекается достаточно успешно.

Если говорить о недавних инициативах ВО3, то одна из них направлена на решение проблемы отсутствия полных статистических данных о масштабах оборота фальсифицированной медицинской продукции и причиненном ей ущербе. Поэтому основными формами работы ВО3 стала информационно-разъяснительная работа, разработка нормативов и стандартов, а также оказание технической поддержки заинтересованным государствам. Начиная с 2007 года международное сотрудничество по противодействию медицинскому контрафакту перешло на новый качественно новый уровень.
На основании Резолюции WHA65.19 15 в 2012 - 2013 гг. в странах Европейского региона и Западного региона Тихого океана реализовывался пилотный мониторинговый проект, направленный на получение информации относительно противодействия обращению некондиционной, поддельной, ложно маркированной, фальсифицированной, контрафактной медицинской продукции (substandard/spurious/falsely labeled/ falsified/counterfeit medical products - SSFFC). Цель проекта - сбор данных с целью последующей выработки рекомендаций по предотвращению обороту данной продукции, ее попаданию в легальную сеть, а также выяснению того, какие именно лекарственные средства в нее попадают. Кстати говоря, реализация данного проекта выявила проблему недостаточной лабораторной базы, в особенности в развивающихся государствах. Другая цель проекта - апробирование взаимодействия международных и национальных структур.

\section{2. ВОЗ: эволюция понимания фармацевти-} ческого контрафакта. Вполне понятно, что новый уровень координации международных усилий предполагает процесс постоянного уточнения используемых понятий, в частности, понятия «контрафактные лекарственные средства», что постоянно осуществляется на уровне ВО3 и стало предметом самостоятельного предмета доктринального анализа ${ }^{16}$. Толчком для этого послужило обсуждение содержания данного понятия в Исполкоме ВО3 в январе 2009 года и общем контексте дебатов на 62-ой сессии Всемирной ассамблеи здравоохранения в 2009 году ${ }^{17}$. В результате обсуждений была высказана озабоченность по поводу использования данного термина по причине наличия целой серии его эквивалентов - фальсифицированные, поддельные, сфабрикованные,

\footnotetext{
15 Всемирная ассамблея здравоохранения. Резолюция WHA65.19 «Некондиционная/поддельная/ложно маркированная/фальсифицированная/контрафактная медицинская продукция // http://apps.who.int/medicinedocs/documents/s19994ru.pdf (дата обращения: 20.03.2014 г.).

${ }^{16}$ Counterfeit Medicines and Organized Crime. Turin: United Nations Interregional Crime and Justice Research Institute, 2012. P. $12-17$.

17 См.: WHA62/2009/REC/3, протоколы пятого заседания Комитета Ф, раздел 2 , десятого заседания Комитета А, раздел 1 , и третьего заседания Комитета В, раздел 3.
} 
некачественные. Это обстоятельство ставит под сомнение возможность исчерпывающего определения данного термина. Обеспокоенность по поводу использования данного термина была высказана в п. 2 Доклада Секретариата «Контрафактная медицинская продукция» ${ }^{18}$.

В экспертных кругах ВОЗ была проведена работа по исследованию использования понятия «контрафактное лекарственное средство» в контексте определений, содержащихся в национальных законодательствах ${ }^{19}$. Анализ показал, что $31 \%$ государств-членов ВОЗ вообще не имеют законодательных определений понятия «контрафактное лекарственные средства», 4\% государств используют этот термин исключительно для описания нарушения прав ИС, преимущественно товарных знаков (развитые государства, ЕС). В ряде стран нарушение прав ИС включается в определение, но не выступает исключительным критерием. Среди оставшихся $65 \%$ государств $17 \%$ государств в качестве родового признака контрафакта указывают его преднамеренный характер, а 48\% используют энумеративный тип определений.

В российском законодательстве установлены следующие определения. В соответствии с п. 37 ст. 4 «Основные понятия» Федерального закона от 12 апреля 2010 года № 61 - Ф3 (в редакции от 12 марта 2014 года) «Об обращении лекарственных средств» под фальсифицированным лекарственным средством понимается лекарственное средство, сопровождаемое ложной информацией о его составе и (или) производителе. Недоброкачественное лекарство определяется как лекарственное средство, не соответствующее требованиям фармакопейной статьи либо в случае ее отсутствия требованиям нормативной документации или нормативного документа (п. 38). И, наконец, под контрафактным лекарственным средством понимается лекарственное средством,

\footnotetext{
${ }^{18}$ ВОЗ. 63-я сессия Всемирной Ассамблеи здравоохранения. Пункт 11.20 предварительной повестки дня. Контрафактная медицинская продукция. Доклад Секретариата. А63/23 (22 апреля 2010 г.) // http://www.who.int/gb/ebwha/pdf_files/ WHA63/A63_23-ru.pdf (дата обращения: 15.04.2014 г.).

19 Preliminary Draft Survey on National Legislation on «counterfeit medicines». WHO. Working document WHO/ACM/1 (4 May 2010) http://www.who.int/medicines/services/counterfeit/ WHO ACM Report.pdf (дата обращения: 15.04.2014 г.).
}

которое находится в обороте с нарушением гражданского законодательства (п. 39). Таким образом, критерий контрафакта - противозаконность.

Вместе с тем контрафакт противоречит не только гражданскому законодательству, как об этом сказано в Законе, но и уголовному и административному законодательству, в том числе законодательным положениям о защите прав ИС. Поэтому надо признать, что и фальсификация также является противозаконной. Именно это нашло свое отражение в более полном определении фальсифицированного лекарственного средства, даваемого ВО3 (где??? дается): «продукт, преднамеренно и противозаконно снабженный маркировкой, искажающей подлинность и/или изготовителя». Однако недостатки указанных законодательных определений во многом вызваны расплывчатым характером содержательных границ между понятиями подделка, фальсификат, контрафакт, что нашло свое выражение во взаимозаменяемости различных английский терминов «counterfeit», «fake», «false», «adulterine».

C нашей точки зрения, в широком смысле контрафакт - это фальсифицированная, т.е. поддельная продукция (не всегда низкого качества), которая в случае установленного нарушения прав ИС (незаконного использования запатентованных решений, чужой товарной марки) должна считаться контрафактом в узком смысле слова. Поэтому можно согласиться с тем, что контрафакт - это вещи, содержащие результаты интеллектуальной деятельности и (или) приравненные к ним объекты, которые были изготовлены или использованы при отсутствии необходимого разрешения обладателя исключительного права на соответствующие объекты ${ }^{20}$.

В настоящее время только в законодательстве США и Филиппин включены развернутые определения контрафактных лекарственных средств. Определение, принятое в США, базируется на концепции товарных знаков, нарушение которых определяет фармацевтический продукт как контрафактный. Так, в гл. 2 Акта США о пищевых

\footnotetext{
${ }^{20}$ Иванов Н.В. Понятие, признаки и структура контрафакта // Интеллектуальная собственность. Контрафакт. Актуальные проблемы теории и практики: сб. науч. трудов. Т.2 / Под ред. проф., доктора юрид. наук В.Н. Лопатина. М.: Издательство Юрайт, 2009. С. 48.
} 
продуктах, лекарствах и косметике (United State of America Federal Food, Drug and Cosmetics Act) фальсифицированное лекарство определяется как лекарство, которое, или упаковка и маркировка которого, без соответствующего разрешения содержит товарный знак, наименование компании или другой идентификационный знак, оттиск эмблему или любое иное изображение производителя лекарства, переработчика, упаковщика или распространителя, отличного от того лица или лиц, которые в действительности произвели, переработки, упаковали или распространили такое лекарство; и которое незаконным образом претендует на то, что является продукцией того другого производителя лекарства, переработчика, упаковщика или распространителя или выдается за него, или упаковывается и распространяется от его имени» ${ }^{21}$.

В законодательстве Филиппин определение контрафактной фармацевтической продукции фокусируется преимущественно на методах, посредством которых продукт может быть фальсифицирован, а покупатель обманут. Данное определение включает несколько возможных случаев и видится как в целом согласующимся с духом определения, предложенного ВОЗ в 1992 году 22.

Достаточно интересно, что некоторые африканские государства также идут по пути подведения понятия фармацевтический контрафакт под критерий нарушения прав ИС. Так, в соответствии с Законом Кении о борьбе с контрафактными лекарственными средствами, который был принят в 2008 году, термин «контрафактная деятельность» предполагает выполнение действий без разрешения владельца прав на интеллектуальную собственность Кении или на территории других стран в отношении товаров, права на которые защищены» ${ }^{23}$. Отсюда следует, что нарушение патентных прав и прав на товарные знаки

\footnotetext{
${ }^{21}$ United States of America Federal Food, Drug and Cosmetics Act (As Amend through December 31 2004). Subchapter II-Definitions // http://wipo.int/wipolex/en/text.jsp?file_id=17863 (дата обращения: 11.03.2014 г.).

${ }^{22}$ The Philippines Republic Act Special Law on Counterfeit Drugs, no. 8203(1996) // http://www.wipo.int/wipolex/en/details. jsp?id=9943 (дата обращения: 11.03.2014 г.).

${ }^{23}$ Kenya Anti-Counterfeit Bill (2008) // http://info-justice.org/ wp_content/uploads/2012/04/Kenya-AC2008.pdf (дата обращения: 18.01.2014 г.).
}

квалифицируется в качестве контрафактной деятельности. Такой подход затрудняет борьбу с фальсифицированными дженериками и, следовательно, не позволяет бороться с нарушениями прав человека на жизнь и здоровье. Поэтому в своем Постановлении от 21 Апреля 2012 года Верховный суд Кении признал, что права ИС не должны ставиться выше жизни и здоровья и не должны превалировать над правом на жизнь и здоровье. Соответственно, это предполагает пересмотр закона, строгое исполнение которого подрывает доступ к приемлемым по ценовым показателям дженериковым препаратам.

В сущности, подавляющее число стран предпочитает классифицировать различные виды фальсифицированной продукции и подводить их под понятие «контрафактная продукция», которое в свою очередь остается нераскрытым. С другой стороны, если под данной продукцией понимать только продукцию, произведенную и реализованную с нарушением исключительных прав, то вне поля внимания может оказаться продукция, которая создает серьезный риск для здоровья и безопасности потребителей.

Многообразие легальных определений фальсифицированной и контрафактной продукции не только затрудняет сотрудничество государств, но и не позволяет делать окончательные выводы о всем масштабе глобальной проблемы контрафакта медицинской продукции. Однако несмотря на то, то в оборот было введено понятие «некондиционная/поддельная/ложно маркированная/фальсифицированная/контрафактная медицинская продукция», ВОЗ не отказалась от использования данного термина и пошла по пути выработки более системного понимания явления, которое в нем отражается.

Понимание фальсифицированной продукции получило свое отражение в Итоговом Проекте принципов IMPACT ${ }^{24}$. Целевая группа определяет ее как продукцию, в отношении которой создается ложное представление о ее идентичности (названии, составе, действенности, или любых

\footnotetext{
${ }^{24}$ IMPACT. Draft Principles and Elements for National Legislation against Counterfeit Medical Products. Background document for a meeting of experts (Lisbon, 10 - 11 December 2007) // http://www. who.int/impact/events/PrinciplesElementsforNationalLegislation. pdf (дата обращения: 18.01.2014 г.).
} 
других элементов, которые могут влиять на решение профессионалов в сфере здравоохранения, пациентов или покупателей в отношении идентичности продукта) или источнике (производителе, стране производства, стране происхождения, или другой любой элемент, который может повлиять на решение профессионалов /специалистов в сфере здравоохранения, пациентов или покупателей о источника продукта). Это распространяется на продукты, а также на информацию о таре, другой упаковке или этикетке. В число контрафактных продуктов могут попасть и продукты с торговой маркой и дженерики. Контрафактные продукты могут включать продукты с корректными компонентами или с неправильными компонентами, без активных ингредиентов, с ненадлежащими активными ингредиентами или с ложной упаковкой. Анализируя это определение мы не увидим здесь такого элемента контрафакта как нарушение прав ИС.

Это вызвано тем, что не во всех случаях контрафакт в указанном смысле данного термина сопровождается нарушением прав ИС. В перечне полномочий Целевой группы, в сжатом виде предусмотренных еще в Римской Декларации 2006 года, рассмотрение вопросов нарушения прав ИС при производстве и распространении контрафактной медицинской продукции не упоминается ${ }^{25}$. Более того в п. 10 Доклада Секретариата ВОЗ о работе IMPACT ${ }^{26}$ прямо отмечается, что существует однозначный консенсус среди участников Целевой группы о том, что медицинский контрафакт не следует путать с вопросами, относящимися к медицинской продукции, которые не разрешена для продажи в данной стране, ни с вопросами, касающимися товарных знаков или соответствующих правам ИС. Отмеченные обстоятельства отражают специализацию ВО3, под эгидой которой работает Группа. Но одновременно это не свидетельствует об игнорировании Целевой Группой

\footnotetext{
${ }^{25}$ International medical products Anti-Counterfeiting Taskforce (IMPACT). Terms of Reference // http://www.ccapcongress.net/ archives/Geneva/Files/Reggi.pdf.

${ }^{26}$ WHO. Counterfeit medical products. International Medical Products Anti-Counterfeiting Taskforce. Report by the Secretariat. A/62/14 (30 April 2009) // http://www.coe.int/t/dghl/standardsetting/medicrime/WHA\%20A62_14-en.pdf (дата обращения: 19.01.2014 г.).
}

комплексного характера феномена контрафакта. Поскольку в данном пункте говорится о том, что в ведении ВО3 находится именно контрафакт медицинской продукции, затрагивающий здоровье населения, тогда как другие аспекты контрафакта принимаются во внимание в соответствии с мандатами других органов или международных организаций.

Если мы обратимся к п. 1 Итогового проекта Принципов, то здесь четко оговаривается, что контрафакт медицинской продукции нуждается в том, чтобы он был принят во внимание различными отраслями законодательства - в сфере защиты и осуществления ИС, регулирования и контроля за обращением лекарственных средств и медицинских устройств, а также уголовного права. Все эти отрасли законодательства должны быть уместны для предупреждения и пресечения контрафакта. Однако далее следует ремарка о том, что Принципы, предназначенные быть основой для законодательных мер в отношении контрафакта, фокусируются на последствиях контрафакта для общественного и индивидуального здоровья, поэтому именно в этом аспекте они должны быть приняты соответствующим образом во внимание национальными законодательствами. Специальное национальное и/или региональное уголовное, фармацевтическое, административное и гражданское законодательство может нуждаться в том, чтобы быть обогащенным данными Принципами, которые нацелены на дополнение, а не на замену этих отраслей национального права.

Далее четко определяется, что Принципы специально не адресованы нарушениям в аспекте прав ИС, включая патентные права, как и аспектам параллельного импорта и иной незаконной деятельности, такой как обход поставок легальной медицинской продукции или ее хищение. Однако это нисколько не умаляет предложенный проект Принципов, которые содержат исчерпывающий перечень обязательств государственных институтов, производителей и дистрибъютеров, розничных продавцов и позволяющих предотвращать и пресекать производство и распространение медицинского контрафакта. Во всех деталях прописаны обязательства в сфере международного сотрудничества, природа и система уголовных санкций.

В 2008 году на своей третьей встрече Целевая международная группа IMPACT предложила 
более всеохватное определение контрафактных

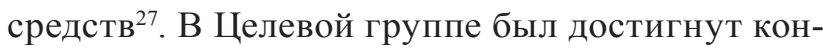
сенсус относительно того, что вопрос о контрафактных лекарственных средствах не следует смешивать ни с вопросами, относящимися к лекарственными средствам, которые разрешены для продажи в определенной стране, ни с нарушениями или спорами в отношении патентов, ни в отношении того, что любые меры против контрафактной медицинской продукции не должны препятствовать международной торговле законными дженериками.

В соответствии с данным определением, под «контрафактными» медицинскими изделиями следует понимать изделие с ложным отображением его идентичности и/или источника. Это относится к самому изделию, его обертке или иной упаковке или информации, содержащейся в маркировке. Данное определение предполагает, что контрафакт может относиться как к фирменным изделиям, так и к изделиям-дженерикам. Понятие «контрафактный» может включать изделия с правильными ингредиентами/компонентами, с ложными ингредиентами/компонентами, без активных ингредиентов, с неправильным содержанием активных ингредиентов или с поддельной упаковкой. Далее Группа отметила, что нарушения или споры в отношении патентов не следует смешивать с контрафактом медицинской продукции. Медицинская продукция, как оригинальная, так и дженериковая, не разрешенная в одной стране, но разрешенная в другой, не должна считаться «контрафактной». И, наконец, некондиционные партии законно изготовленной медицинской продукции и дефекты качества, а также несоответствие с надлежащей практикой изготовления или распространения также не следует смешивать с контрафактом.

В 2010 году на 63-й сессии Всемирной ассамблеи здравоохранения было предложено создать Межправительственную рабочую группу, которая должна рассматривать вопросы предупреждения появления некондиционной/поддельной/ложно маркированной/фальсифицированной/контрафакт-

\footnotetext{
${ }^{27}$ Third IMPACT General Meeting (3 - 5 December 2008, Hammamet, Tunisia). Summary Report. Para $11 / /$ http://www.who. int/impact/resources/IMPACTthirdgeneralmeeting_\%20report.pdf (дата обращения: 11.04.2014 г.).
}

ной медицинской продукции. Созданная Рабочая группа ВОЗ по некондиционной/поддельной/ложно маркированной/фальсифицированной/контрафактной медицинской продукции того, что по признанию многих экспертов термин «контрафактное лекарственное средство», приемлемое в 1988 году, в настоящее время отстало от жизни, что связано с произошедшими международными изменениями. Объективной тенденций является то, что данный термин все более воспринимается в связи с нарушениями прав ИС, а не с проблемами общественного здравоохранения. Поэтому эксперты ВОЗ считают необходимыми найти компромисс. В целях акцентирования внимания на проблемах общественного здравоохранения при разработке соответствующих нормативов и стандартов, предлагается заменить «контрафактный» на «фальсифицированный» и зарезервировать термин «контрафактное лекарственное средство» за фальсифицированным лекарственным средством с контрафактным торговым знаком в соответствии с существующим определением ВОИС ${ }^{28}$. В результате Группа признала, что выпуск контрафакта может затрагивать как фирменную продукцию, так и дженерики. Далее было отмечено, что некондиционная/поддельная/ ложномаркированная/фальсифицированная/контрафактная медицинская продукция может включать продукцию с правильными или неправильными ингредиентами, без активных ингредиентов, с недостаточными активными ингредиентами или в поддельной упаковке.

Таким образом, в сущности, Рабочая группа предложила под понятием контрафактное лекарственное средством понимать именно «фальсифицированное лекарственное средство», чтобы не ассоциировать его с преимущественным нарушением прав ИС. В частности, в преамбуле Резолюции Всемирной Ассамблеи здравоохранения WHA65.19 подчеркивалось, что борьба с

\footnotetext{
${ }_{28}$ Рабочая группа ВО3 по некондиционной/поддельной/ ложно маркированной/фальсифицированной/контрафактной медицинской продукции. Пункт 5 предварительной повестки дня. Роль ВОЗ в предупреждении и борьбе с медицинской продукцией, качество, безопасность и эффективность которой не вызывают доверия, такой как некондиционная/ поддельная/ложно маркированная/фальсифицированная/ контрафактная медицинская продукция. Пункт 26 // WHO. A/SSFFC/WG/3Rev.1 (17 февраля 2011) // http://apps.who.int/ gb/ssffc/pdf_files/A_SSFFC_wg3Rev.1-ru.pdf (дата обращения: 15.01.2014 г.).
} 
медицинским контрафактом не должна вести к ограничению не запрещенных законом дженериков ${ }^{29}$. Далее уже в п. 4 Ассамблея постановила создать новый механизм межгосударственного сотрудничества по вопросам общественного здравоохранения, за исключением соображений, касающихся торговли и ИС. в отношении к фальсифицированной и контрафактной продукции. Именно это позволяет квалифицировать работу ВО3 по противодействию медицинскому контрафакту именно с точки зрения интересов общественного здравоохранения, но при дополнении работы других учреждений $\mathrm{OOH}$ в этой области, например, Управления ООН по наркотикам и преступности, ВОИС, ВТО.

Вместе с тем не надо думать, что ВОЗ позиционирует в качестве специализированной организации исключительно по противодействию медицинскому контрафакту. Дело в том, что данное направление ее работы выступает в качестве вспомогательного для осуществления ее главной миссии, а именно - осуществление мер по обеспечению наличия качественной, безопасной, эффективной и доступной медицинской продукции. Это достигается путем координации сотрудничества организации с государствами в направлении разработки национальной политики в области лекарственных средств, формировании и развитии системы управления рисками, устойчивого финансирования, развития кадрового потенциала, создания надежной системы закупок, рациональному отбору и использованию качественной медицинской продукции и т.д. Основополагающая роль ВОЗ в обеспечении качества, безопасности и эффективности медицинской продукции, в расширении доступа к приемлемым по цене, качественным, безопасным и эффективным лекарственным средствам, а также оказание помощи в этом развивающимся и наименее развитым странам была подтверждена в преамбуле и п. 1 Резолюции Всемирной Ассамблеи здравоохранения WHA65.19³.

29 Всемирная ассамблея здравоохранения. Резолюция WHA65.19 «Некондиционная/поддельная/ложно маркированная/фальсифицированная/контрафактная медицинская продукция // http://apps.who.int/medicinedocs/documents/s19994ru.pdf (дата обращения: 15.01.2014 г.).

30 Всемирная ассамблея здравоохранения. Резолюция WHA65.19 «Некондиционная/поддельная/ложно маркирован-
Решение проблемы пагубных последствий медицинского контрафакта предполагает решение такой проблемы, как сокращение объемов оборота и, следовательно, уменьшения степени доступности контрафактной лекарственной продукции особенно для лечения пандемических заболеваний. Одновременно организация постоянно подчеркивает, то одних только регулятивных мер, на совершенствование которых, собственно, и направлена ее работа, для устранения контрафакта как преграды для доступа к качественным лекарственным средствам явно недостаточно ${ }^{31}$. Далее в п. 27 Рабочая группа, перейдя к использованию понятия фальсифицированные лекарственные средства, отметила, что данные средства представляют собой не просто некондиционные (некачественные) лекарства, а фальшивые лекарственные средства. Их производителя и дистрибъютера трудно найти, поэтому противодействие обороту данной продукции выходит за обычные рамки регулятивного контроля. В этом случае необходимо сотрудничество регулятивных органов и других национальных организаций с отделами криминалистических расследований, таможенными службами и другими правоприменительными учреждениями.

Однако не следует думать, что решение проблемы доступности лекарственных средств сводится только к повышению эффективности предупреждения и пресечения деятельности по фальсификации медицинской продукции посредством уголовных мер. Доступность - это комплексная проблема, которая включает в себя вопросы научно-технологической, ценовой, социальной политики, а также политики международного научно-технологического сотрудничества

ная/фальсифицированная/контрафактная медицинская продукция // http://apps.who.int/medicinedocs/documents/s19994ru.pdf (дата обращения: 13.03.2014 г.).

${ }^{31}$ Рабочая группа ВОЗ по некондиционной/поддельной/ ложно маркированной/фальсифицированной/контрафактной медицинской продукции. Пункт 5 предварительной повестки дня. Роль ВОЗ в предупреждении и борьбе с медицинской продукцией, качество, безопасность и эффективность которой не вызывают доверия, такой как некондиционная/ поддельная/ложно маркированная/фальсифицированная/ контрафактная медицинская продукция. Пункт 23 // WHO. A/SSFFC/WG/3Rev.1 (17 февраля 2011) // http://apps.who.int/ gb/ssffc/pdf_files/A_SSFFC_wg3Rev.1-ru.pdf (дата обращения: 13.03.2014 г.). 
и политики в сфере защиты прав ИС. Важный элементом в решении проблемы доступности медицинской продукции является уголовно-правовая политика и международное сотрудничество в уголовной сфере.

Координация сотрудничества на международном уровне потребовала не только уточнения используемых понятий, но и установления комплекса причин увеличения оборота медицинской контрафактной продукции. С нашей точки зрения, именно тот комплекс причин одновременно мотивирует возможные нарушения прав ИС. К причинам увеличения потоков фальсифицированной (контрафактной) медицинской продукции ВО3, осуществляющая мониторинг безопасности лекарственных средств, относит мотивы получения организованной преступностью огромных доходов. Это становится возможным благодаря недостаткам соответствующего законодательства, отсутствию или слабости регулирующих органов, неадекватному осуществлению существующего законодательства и неэффективным уголовным санкциям ${ }^{32}$.

К причинам можно еще также отнести коррупцию и конфликт интересов, высокие цены, неэффективность взаимодействия органов власти, неэффективное регулирование в экспортирующих странах и зонах свободной торговли. Увеличение объемов контрафактной продукции коррелирует изменению ее природы вызвано также возникновением новых и ухищренных маркетинговых сетей, наличием возможности экспортного транзита через зоны свободной торговли. В результате выгоды от контрафакта во многом превосходят риски, связанные с данной деятельностью по сравнению с другими формами преступной экономической деятельности - торговлей людьми, отмыванием денег и наркоторговлей. Это позволяет говорить об изменении природы контрафактной деятельности по сравнению с предыдущими столетиями. К одному из таких изменений относится связь с финансированием наркотрафика и терроризма. На это обстоятельство указывалось в п. Е Декларации Европарламента от 26 июня 2003

\footnotetext{
${ }^{32}$ WHO. Counterfeit medical products. Report by the Secretariat para. 7. A/62/13 (30 April 2009) // http://www.coe.int/t/dghl/ standardsetting/medicrime/WHA\%20A62_13-en.pdf (дата обращения: 15.01.2014 г.).
}

года о пиратстве и контрафакте в расширенном Европейском Союзе ${ }^{33}$.

Не последнюю роль в увеличении оборотов контрафактной продукции сыграл НТП, например, что касается производства копии упаковок. Вполне очевидно, что по мере дальнейшего НТП и особенно цифровых технологий возникают предпосылки для ускорения и удешевления производства подделок. В результате современные имитации практически неотличимы от подлинных изделий. Причем имитации подвержен не только внешний дизайн, но состав продукции, являющийся опасным для жизни и здоровья, как это имеет место в фармацевтике. Однако НТП создает условия и для развития технических мер защиты (штрих-коды, голограммы). Инновационным шагом стало внедрение компанией «Bristol-Myers Squibb» методов технической защиты с использованием генной инженерии для защиты онкологических и антиретровирусных средств. Однако эти меры приводят к удорожанию продукции в среднем на 15 - 20\% и преодолеваются через то или иное время фальсификаторами.

Помимо современной технологической базы контрафакт становится возможным и благодаря определенным действия законных производителей, в частности, «утечкам» или неосмотрительности служащих компаний, обладающих известными брендами, а иногда и благодаря деятельности лицензионных поставщиков и производителей, которые превышают разрешенные объемы производства объемы с целью продажи дополнительной продукции на стороне. Не последнюю роль в «успехах» фальсификаторов играет господство стереотипа о контрафакте как в целом безобидной деятельности и готовность определенной части потребителей сознательно приобретать и использовать контрафактную продукцию.

Определенное место в системе факторов фальсификации медицинской продукции играет также высокая стоимость тех препаратов, которые относятся к запатентованным лекар-

\footnotetext{
${ }^{33}$ European Parliament declaration on the fight against piracy and counterfeiting in the enlarged EU (Strasbourg, 5 June 2003) // http://www.europarl.europa.eu/side/getDoc.doreference=P5 $\mathrm{TA}(200300275 \&$ language $=\mathrm{PL}=\mathrm{BKMD}-33$ (дата обращения: 16.01.2014 г.).
} 
ственным средствам, что определяет их высокую стоимость. В общем объеме лекарственных средств таковых немного - около 4\%, но и подделка не только противоречит интересам правообладателей, но и в конечном счете также угрожает здоровью населения.

Четкое понимание причин медицинского фальсификата стало основой предложенных ВОЗ мер по противодействию данному явлению. Они в основном направлены на улучшение работы по выявлению фальсифицированных препаратов как органами контроля качества, так и всеми участниками процесса производства, распространения, продажи и потребления лекарственных средств. Сюда также относится усиление законодательной базы, в том числе усиление ответственности за производство и продажу лекарственных средств, на разработку стандартных операционных процедур и руководств по данному вопросу для национальных регулирующих органов и по совершенствованию лицензирования производства, импорта, распределения, поставки и продажи лекарственных средств. Важнейшим достижением стало принятие в 1994 году на основании резолюции WHA47.13 Программы действий ВО3 по основным лекарственным средствам (1994 г.), а также подготовка Секретариатом ВО3 в 1998 году Руководящих указаний по разработке мер борьбы с «контрафактными» лекарственными средствами ${ }^{34}$.

Глобализация фальсификации медицинской продукции предполагает принятие четких мер, которые должны осуществляться не только индивидуально, но и в режиме международного сотрудничества. Во-первых, это меры информационного порядка, усиливающие координацию регуляторных органов на национальном и международном уровне. Во-вторых, это гармонизация уголовных законодательств. И, в-третьих, дальнейшее совершенствование защиты прав ИС. К этому перечню можно было добавить добросовестность и осмотрительность как врачей, так и самих пациентов, а также

\footnotetext{
${ }^{34}$ Doc. WHO/EDM/QSM/99.1. (Контрафактные лекарства - руководство по мерам борьбы с контрафактными лекарствами. Женева, 1999.) Department of essential drugs and other medicines. Guidelines for the development of measure to combat counterfeit drugs. Geneva: World Health Organization, 1999 // http:/www. who.int/medicines/publications/counterfeitguidelines (дата обращения: 15.01.2014 г.).
}

активность законных производителей фармацевтической продукции. В качестве примера можно привести Институт фармацевтической безопасности, созданный в Европе по инициативе фармацевтических компаний ${ }^{35}$. В его функции входит отслеживание фальсификации продукции компаний-участников, сбор и анализ данных со всего мира, предупреждение аптек об опасных препаратах и т.д. И, наконец, на решение задачи противодействия обороту фальсифицированной и некачественной медицинской продукции направлена серия стандартов наилучшей практики - надлежащая производственная практика (GMP), надлежащая дистрибъютерская практика (GDP), надлежащая аптечная практика (GPP) и т.д.

3. ВОЗ и ВОИС: специфика подходов к фармацевтическому контрафакту. Все сказанное позволяет сделать вывод о том, что проблематика защиты прав ИС, нарушаемых фальсификацией медицинской продукции, учитывается ВО3, но не становится специальным предметом ее деятельности. Достаточно интересно в качестве сравнения сопоставить подход данной организации, например, с подходом Всемирной организации интеллектуальной собственности (далее-ВОИС) - международной организации, специализирующейся в сфере защиты прав ИС. Дело в том, что хотя в определение фальсифицированной фармацевтической продукции критерий нарушения прав ИС прямым образом не включается, фальсификация затрагивает интересы обладателей патентов и товарных знаков. Поэтому такие международные неправительственные организации, как Ассоциация международных фармацевтических производителей и Коалиция в защиту прав ИС отслеживают статистику причинения ущерба правообладателям, т.е. фармацевтическим предприятиям, от оборота медицинского контрафакта.

Как отмечается в одном из документов Постоянного комитета ВОИС по патентному праву (далее - ПКПП), «фальсифицированная медицинская продукция подрывает общественное доверие к медицинским методам лечения и системе здравоохранения в целом, представляют серьезную угрозу для здоровья и жизни пациентов, принимающих такие лекарственные

\footnotetext{
${ }^{35}$ www.psi@psi-inc.org (дата обращения: 15.01.2014 г.).
} 
средства, вследствие отсутствия терапевтического эффекта или токсичности. Потенциально опасны для здоровья пациентов абсолютно все фальсификаты, поскольку они не подвергаются при производстве предусмотренном для легальной продукции контролю качества и на практике не могут быть идентифицированы конечным потребителем» ${ }^{36}$.

Внимание ПКПП к проблеме контрафактной и фальсифицированной медицинской продукции является составной частью более широкого вопроса доступности лекарственных средств. Обсуждение данного вопроса была начато на 16-й сессии ПКПП в 2011 году. На 18-й сессии ПКПП был сделан вывод о том, что медицинский контрафакт негативным образом воздействует на решение проблемы физической доступности лекарственных средств. К экономическому аспекту доступности относится противоречивое воздействие патентной системы. Учитывая тенденции все большего проникновения контрафактной медицинской продукции в цепочку лекарственного обеспечения и увеличения объемов международной торговли лекарственными средствами, особенно через Интернет, а также расширение масштабов деятельности международной организованной преступности был сделан вывод о необходимости выработки единой политики государств в сфере борьбы с поддельной медицинской продукцией, развития международного сотрудничества и гармонизации национальных законодательных и правоприменительных систем. Другими словами, контрафакт медицинской продукции не только угрожает международной безопасности, но и создает барьеры на пути физической доступности медицинской и в ее составе фармацевтической продукции, что имеет самое негативное воздействие на реализацию прав человека.

Для ПКПП важно, что помимо социальных и человеческих потерь следует упомянуть экономические потери. Они проявляются в уменьшении налогооблагаемой базы, возникновении новой формы недобросовестной конкуренции,

\footnotetext{
${ }^{36}$ ВОИС. Постоянный комитет по патентному праву. Восемнадцатая сессия. Женева, 21 - 25 мая, 2012. Патенты и здравоохранение: Комментарии стран-членов Постоянного комитета по патентному праву (ПКПП) и наблюдателей. SCP/18/INF/3. Приложение (11 апреля 2012 года) // http://www.wipo.int/ edocs/mdocs/scp/ru/scp_18/scp_18_inf_3.doc (дата обращения: 15.01.2014 г.).
}

снижении доходов законных производителей. В том случае, если контрафакт нарушает права ИС, то это причиняет ущерб не только интересам правообладателей, но и ущерб инновационному развитию экономики, поскольку затрагивает один из ее основополагающих принципов, а именно справедливое вознаграждение исследователей.

К одной из проблем универсального международного сотрудничества относится проблема дублирования в деятельности международных организаций в борьбе с контрафактом была затронута на 18-ой сессии ПКПП (май 2012 года). Большинство представителей Комитета признали, что к компетенции ВОИС не относится проблема фальсифицированных и некачественных лекарств, поскольку эти вопросы не имеют никакого отношения к патентной сфере, поэтому ВОИС не полномочна обсуждать эти тему. Комитет, принимая во внимание то, что патент на фармацевтический продукт выдается на основании критериев патентоспособности, предусмотренных в национальном законодательстве, но не на основании качества и безопасности лекарственных средств, признал лидерство ВОЗ в обсуждении вопроса о соотношении ИС, здравоохранения и инноваций в рамках Глобальной стратегии ВОЗ в этом вопросе. Напомним, что в 2003 году ВОЗ создала Комиссию по по исследованию взаимосвязи между правами ИС, инновациями и здравоохранением (CIPIN). B 2006 году по этому вопросу был подготовлен доклад ${ }^{37}$, который был положен в основание принятой в 2008 году Глобальной стратегии и плана действий в области общественного здравоохранения, инноваций и ИС.

Если обратиться к позициям экспертов или различных фармакологических ассоциаций из развивающихся стран, то для них контрафакт и нарушение прав ИС - две непересекающиеся сферы. Так, ALFAR (Латиноамериканская ассоциация фармацевтической промышленности) в ходе дискуссий в Постоянном комитете ВОИС по патентному праву высказала позицию о том,

\footnotetext{
${ }^{37}$ Public health, innovation and intellectual property rights. Report of the Commission on intellectual property rights, innovation and public health. Geneva: World Health organization, 2006. http:// www.who.int/intellectualproperty/documents/thereport/ENPublicHealthReport.pdf (дата обращения: 18.03.2014 г.).
} 
что вопрос торговли поддельными и недоброкачественными лекарствами находится далеко за пределами компетенции Постоянного комитета и ВОИС и более того не имеет никакого отношения к патентам и защите прав на них ${ }^{38}$.

B обоснование своей позиции ALFAR сослалась на определение фальсифицированных лекарственных средств, приведенное в Руководстве ВО3 по противодействию контрафактным лекарствам. «Фальсифицированное лекарство - это лекарство, намеренно сопровождаемое вводящей в заблуждение информацией о его составе или производителе. Подделываются как лекарства известных производителей, так и дженерики, это могут быть изделия с правильными и неправильными ингредиентами, с недостаточным количеством действующего вещества или поддельной упаковкой» ${ }^{39}$. ALFAR напомнила, что подделываются как запатентованные лекарства, так и лекарства, находящиеся в свободном доступе. Поэтому, как считает ALFAR, для борьбы с фальсифицированными лекарствами нет необходимости прибегать к защите прав ИС, а нужно обеспечить строгое правоприменение в области производства и распространения лекарств, включая меры уголовного преследования, если они предусмотрены в национальном законодательстве.

Основываясь на этой позиции ALFAR высказалась против включения, как это предлагалось США на 17 сессии Постоянного комитета ВОИС по патентному праву ${ }^{40}$, в юридическую концепцию оборота поддельных и некачественных лекарств такого признака как возможные нарушения патентных прав. Аналогичного мнения придерживается такой эксперт как К. Сепуч, полагающий, что необходимо принять меры к тому, чтобы из определения «контрафактная продукция» вопрос о нарушении патентных прав был исключен ${ }^{41}$. Поэтому, по мнению дан-

\footnotetext{
${ }^{38} \mathrm{SCP} / 18 / \mathrm{INF} / 3$. Приложение. С. 18.

${ }^{39}$ Department of essential drugs and other medicines. Guidelines for the development of measure to combat counterfeit drugs, Geneva. World Health Organization. 1999. P. 8 // WHO/EDM/ QSM/99.1.

${ }^{40} K$. Сепуч Бороться с контрафактными лекарствами, не причиняя ущерба здоровью населения // http://trad.ecoaccord.org/ bridges/0410/3.htm (дата обращения: 18.03.2014 г.).

${ }^{41} \mathrm{SCP} / 18 / \mathrm{INF} / 3$. Приложение. C. 18.
}

ной Ассоциации, ПКПП не должен дублировать работу ВОЗ в этом направлении, т.е. не должен заниматься вопросом выяснения степени влияния медицинского фальсификата, присутствующего на рынке на доступу к подлинным патентованным или непатентованным лекарствам, поскольку это относится к мандату ВОЗ. Делегация же США своим предложением, по сути, стремилась расширить данный мандат.

Представляется, что поскольку подавляющая масса лекарственных средств являются непатентованными, то, действительно, рассмотрение влияния оборота контрафактной фармацевтической продукции на доступ к непатентованным лекарственным средствам, равно как рассмотрение непатентных барьеров, действительно, является для ПКПП излишним. Предложения же США во многом это определяются тем, что в законодательстве данного государства, как мы уже отмечали, критерий нарушения прав ИС включен в определение фальсифицированного лекарственного средства. Вместе с тем, полностью разводить вопросы защиты прав ИС и защиты права населения на доступ к лекарственным средствам совершенно неверно.

Сопоставление подходов ВОЗ и ВОИС к решению проблемы оборота фальсифицированной медицинской продукции в очередной раз подтверждает, что в сфере противодействия контрафакту сложилось два направления. Одно из них связано с противодействием медицинскому контрафакту с точки зрения защиты здоровья населения и обеспечения доступа к качественным лекарственным препаратам. Другое направление исходит из необходимости защиты прав ИС. Вместе с тем неправильно говорить о том, что защита прав человека (права на жизнь и здоровье) и защита прав ИС - это два непересекающихся аспекта борьбы с контрафактом. Будучи самостоятельными, они находятся в тесном соприкосновении друг с другом.

В отечественной доктрине высказывается взвешенная позиция о том, что основной целью борьбы с фальсификацией средств медицинского применения должна стать защита здоровья населения, а не защита прав ИС. Это связано с тем, что подделка лекарственных препаратов не соответствующего качества наносит существенный, даже непоправимый, в ряде случаев 
смертельный вред здоровью человека, и только лишь финансовый и моральный вред правам правообладателей, да и то не во всех случаях ${ }^{42}$. Сказанное фиксирует тенденцию переноса акцентов в международных усилиях по предотвращению медицинского контрафакта, что ни в коем случае не может быть истолковано как пренебрежение к всесторонней поддержке и защите прав и законных интересов правообладателей. Вести борьбу с контрафактом сразу с двух позиций, в частности, на уровне международных структур, крайне затруднительно. Поэтому в борьбе с медицинским контрафактом существует специализация международных организаций.

В подтверждение данной мысли обратимся к деятельности Большой восьмерки, в частности, к Декларации «Борьба с интеллектуальным пиратством и контрафактной продукцией» (СанктПетербург, 16 июля 2006 года). В п. 1 Декларации заявлена готовность действовать индивидуально и в рамках совместных усилий в борьбе с распространением и торговлей контрафактной продукции. Что самое интересное, признается, что эти усилия будут способствовать устойчивому развитию мировой экономики, в том числе за счет внедрения инноваций, защите здоровья и безопасности потребителей во всем мире. Таким образом в очевидной форме провозглашается двухаспектный подход - борьба с контрафактной продукцией с точки зрения экономики (и, соответственно, интересов правообладателей) и с точки зрения прав человека. Однако уже в п. 2 Группа сосредотачивает свое внимание именно на защите прав ИС от торговли контрафактной продукцией и необходимости интеграции в деятельность международных организаций, осуществляющих инициативы на этом поприще. Таким образом Группа продемонстрировала выбор своей специализации - эффективная защита и обеспечение соблюдения прав ИС.

Для нас интересно, что в п. 3 Декларации среди международных организаций, осуществляющих борьбу с распространение и торговлей контрафактной продукцией упомянут Совет Европы. В п. 4 выделен приоритет - совершен-

42 Терехов А.Ю. Международно-правовые средства предотвращения оборота фальсифицированных лекарственных препаратов. Автореф. ... канд. юрид. наук. М., 2011. С. 6 - 7. ствование и принятие законов, правил и процедур в целях усиления обеспечения соблюдения прав ИС и повышения информированности гражданского общества и деловых кругов о правовых способах защиты обеспечения соблюдения прав ИС, опасности интеллектуального пиратства и контрафактной продукции. Большой акцент был поставлен на тесное сотрудничество между правоохранительными и таможенными органами разных стран.

Если говорить о конкретных мерах, которые изложены в п. 5 (а) Декларации, то сразу же обращает на себя внимание содержательная композиция данных рекомендаций. Группа рекомендует государствам создать информационный сайт с целью доведения до сведения деловых кругов и частных лиц информации о существующих механизмах и процедурах, которые необходимы для защиты и обеспечения соблюдения их прав ИС. И только потом идет рекомендация о доведении до заинтересованных лиц угрозах, которые контрафактная продукция несет общественному здоровью, безопасности, национальным интересам стран, потребителям. Поэтому в соответствии с такой композицией предлагается доводить до сведения меры, предпринимаемые на национальном и международном уровне с целью борьбы с нарушениями ИС. Таким образом, здесь четко обозначена акцентировка Группы именно на защите прав ИС в борьбе с контрафактом. Но это не означает незаинтересованности в другом негативном аспекте пиратства и контрафакта. Поэтому во второй рекомендации, Группа решила поручить ОЭСР подготовить доклад с целью оценки экономических последствий интеллектуального пиратства и распространения контрафактной продукции для национальных экономики и обладателей прав на ИС, а также для общественного здоровья и безопасности.

Далее, что немаловажно, была высказана идея о необходимости в процессе координации с целым рядом международных организаций (ВТО, ВОИС, Всемирной таможенной организации и др.) создавать необходимые условия для борьбы с торговлей контрафактной и пиратской продукцией в заинтересованных странах. В четвертой рекомендации высказано намерение повысить эффективность координации деятельности таможенных служб с целью борьбы с торговлей 
данного рода продукцией и преступностью в сфеpe ИС на границах. Рекомендации завершаются заявлением Группы предпринимать совместные действия для борьбы с тяжкими преступлениями и организованной преступностью в области прав ИС, в том числе посредством совершенствования международной базы в сфере защиты прав ИС. Эти намерения нашли свое подтверждение также в п. 6 Декларации, что в очередной раз подтвердило специализацию Группы.

Если обратиться к рассмотрению деятельности другой структуры - Межрегионального научно-исследовательского института $\mathrm{OOH}$ по вопросам преступности и правосудия (МНИИ) при Комиссии по предупреждению преступности и уголовному правосудию, то в его работе преимущественный интерес представляет собой оценка контрафакции в качестве одного из наиболее серьезных видов организованной преступности и угрозы безопасности потребителей ${ }^{43}$. МНИИ разработал руководящие принципы по вопросу информирования потребителей о продаже фальсифицированных лекарственных средств через Интернет и проводит активную работу в социальных сетях. Но одновременно Институт учитывает такой аспект, как неправомерное использование товарных знаков, что нашло свое отражение в специальном пособии «Борьба с подделкой товарных знаков в трех ведущих европейских государствах - на пути к более всеобъемлющей стратегии» (Fakes: fighting against brand counterfeiting in three key European member States - towards a more comprehensive strategy).

Создавать общий международный документ, который охватил бы все меры на международном и национальном уровне по противодействию контрафакту невозможно. Поэтому мировое сообщество идет по пути создания специализированных международно-правовых документов. Так, вопросам противодействия контрафакту посвящен Договор АCТА, затрагивающая пресечение контрафакта в сфере информационно-коммуникационных технологий. АСТА, ставящий целью непосредственную защиту правообладателей, оговаривает в своей преамбуле, что защита прав ИС не должна быть препятствием развитию торговли. В качестве другого специализированного документа выступает упомянутая выше конвенция Медикрим, ставящая акцент на уголовной защите права человека на здоровье.

В заключение необходимо подчеркнуть, что ни одна из ныне существующих организаций, в том числе ВО3, не может одновременно вести борьбу со всеми негативными аспектами контрафакции медицинской продукции. Однако международные организации должны учитывать, как это демонстрирует ВОЗ и вслед за ней СЕ, что защита здоровья населения и защита такого элемента права человека на здоровье как право на доступ к безопасным и качественным лекарствам и аналогичной медицинской продукции объективным образом сопряжен с необходимостью защиты прав ИС. Однако в связи с тем, что права ИС не относятся к категории международно признанных прав человека, то в борьбе с медицинской контрафакцией именно защита последних выступает приоритетом по отношению к защите первых. В этом заключается особенность подхода BO3 к соотношению различных аспектов противодействия фармацевтическому контрафакту.

\section{Библиография:}

1. Иванов Н.В. Понятие, признаки и структура контрафакта // Интеллектуальная собственность. Контрафакт. Актуальные проблемы теории и практики: сб. науч. трудов. Т.2 / Под ред. проф., доктора юрид. наук В.Н. Лопатина. М.: Издательство Юрайт, 2009. С. 15 - 48.

\footnotetext{
43 Экономический и Социальный Совет ООН. Основные мероприятия Межрегионального научно-исследовательского института ООН по вопросам преступности и правосудия. Доклад Совет попечителей. Раздел В. Контрафакция: участие в борьбе с организованной преступностью // Е/CN.15/2013/21 (12 февраля 2013).
} 
2. Островский А.Н., Новокрещенов И.В., Новокрещенова И.Г., Аранович Л.М., Морозов В.П. Конвенция «Медикрим»: противодействие фальсификации медицинской продукции в области уголовного права // Вестник Росздравнадзора. 2011. № 6. С. 4 - 8.

3. Совет Европы. Конвенция Медикрим. Противодействие фальсификации изделий медицинского назначения и сходным преступлениям. Страсбург: Европейский директорат по качеству лекарственных средств, 2011. 15 с.

4. Терехов А.Ю. Актуальные вопросы международно-правового регулирования предотвращения оборота фальсифицированных лекарственных средств в рамках межправительственных организаций // Евразийский юридический журнал. 2011. № 4. С. 24 - 29.

5. Терехов А.Ю. Международно-правовые средства предотвращения оборота фальсифицированных лекарственных препаратов. Автореф. ... канд. юрид. наук. М., 2011. 23 с.

6. Ушкалова Е.А. Проблемы фальсификации лекарственных средств: фокус на антимикробные препараты // Клиническая микробиология и антимикробная химиотерапия. 2005. T.

7. А.А. Рёрихт. Актуальные проблемы медицинской этики // Философия и культура. - 2010. - № 8. C. 104-107.

8. О. Л. Дубовик, А.А. Рёрихт. Трансплантация органов, тканей и клеток в правовом и криминологическом аспектах // Право и политика. - 2011. - № 12. - С. 104-107.

9. А. Р. Шаяхметова. Обязанности сторон договора возмездного оказания медицинских услуг. // Право и политика. - 2011. - № 2.

10. Н. М. Добрынин, А. Н. Митин. Кому выгодно (cui prodest) нахождение России в ВТО? // Право и политика. - 2012. - № 9. - С. 104-107.

11. О. В. Журкина, И. М. Черевчина, Ю. Л. Беляева. Правовое основание классификации медицинских отходов // Право и политика. - 2012. - № 3. - С. 104-107.

12. Полубинская С.В.. Медицинское право в современном государстве // Право и политика. $-2013 .-$ № 7. - C. 104-107. DOI: 10.7256/1811-9018.2013.7.8981

13. К.И. Коробко. Понятие, признаки, элементы договора на оказание медицинских услуг, заключаемого субъектами частной медицинской практики // Право и политика. $-2010 .-$ № 9.

14. Мальцев А.Е., Мельников О.В. Стандарты в системе здравоохранения и судебной медицине // NB: Российское полицейское право. - 2014. - № 1. - C.135-142. DOI: 10.7256/2306-4218.2014.1.9910. URL: http://e-notabene.ru/pm/article_9910.html

15. М.И. Литовкина. Роль социального государства в обеспечении лекарственной безопасности при реализации конституционного права на охрану здоровья // Право и политика. - 2013. - № 1 . - C. 104-107. DOI: 10.7256/1811-9018.2013.01.5

16. Л. Е. Потеряйко. Рынок донорской крови и ее компонентов как необходимость совершенствования системы медицинского обеспечения населения // Политика и Общество. - 2012. - № 8. - С. 104-107.

17. Жолобова Г.А.. Проблемы правового обеспечения частного и общественного интересов в сфере коммерческой фармацевтической деятельности в России 1881-1912 гг. // Политика и Общество. 2013. - № 10. - C. 104-107. DOI: 10.7256/1812-8696.2013.10.7706

18. Е.Л. Панова. Медикализация здоровья: иллюзия, способная разрушить человека // Философия и культура. - 2012. - № 8. - С. 104-107.

19. Б.И. Алмазова. Современные тенденции правового регулирования медицинской деятельности // Право и политика. - 2010. - № 1 .

20. О.Л. Дубовик, А.А. Рерихт. Человек и медицина: правовые, философские и этические аспекты // Право и политика. - 2009. - № 11.

21. И. И. Нагорная. Предметная характеристика медицинской деятельности как основа ее уголовно-правовой охраны (опыт России, США, Франции) // Право и политика. - 2012. - № 5. - С. 104 107. 7. № 2. C. 167 - 173. 7. Bate R. Fake: The Deadly World of Falsified and Substandard Medi-cines. Washington: AEI Press, 2012. 400 pp. 
22. Chika A., Bello S.O., Jimoch A.O., Umar M.T. The Menace of Fake Drugs: Consequences, Causes and possible Solutions // Research Journal of Medical Sciences. 2011. Vol. 5. Issue 5. P. 258 - 261.

23. Counterfeit Medicines and Organized Crime. Turin: United Nations In-terregional Crime and Justice Research Institute, 2012.119 pp.

24. Davison M. Pharmaceutical Anti-Counterfeiting Combating the Real Danger from Fake Drugs. New Jersey: Wiley, 2011. 426 pp.

25. Wertheimer A., Wang P. (eds.) Counterfeit medicines. Vol. I. Policy, Economics and Countermeasures. Glendale: ILM Publications, 2012. 154 pp.

26. С. Ю. Коблов Правовая охрана изобретений в соответствии с Соглашением по торговым аспектам прав на интеллектуальную собственность (ТРИПС). // Международное право и международные организации / International Law and International Organizations. - 2011. - 4. - C. 137-141.

27. О.В.Маркова Перспективы правовой защиты интеллектуальной собственности и способы укрепления устойчивого элемента системы правовой защиты интеллектуальной собственности // Политика и Общество. - 2012. - 6. - С. 101 - 106.

\section{References (transliteration):}

1. Ivanov N.V. Ponyatie, priznaki i struktura kontrafakta // Intel-lektual'naya sobstvennost'. Kontrafakt. Aktual'nye problemy teorii i praktiki: sb. nauch. trudov. T.2 / Pod red. prof., doktora yurid. nauk V.N. Lopatina. M.: Izdatel'stvo Yurait, 2009. S. 15 - 48.

2. Ostrovskii A.N., Novokreshchenov I.V., Novokreshchenova I.G., Arano-vich L.M., Morozov V.P. Konventsiya «Medikrim»: protivodeistvie fal'si-fikatsii meditsinskoi produktsii v oblasti ugolovnogo prava // Vestnik Ros-zdravnadzora. 2011. № 6. S. 4 - 8.

3. Sovet Evropy. Konventsiya Medikrim. Protivodeistvie fal'sifika-tsii izdelii meditsinskogo naznacheniya i skhodnym prestupleniyam. Stras-burg: Evropeiskii direktorat po kachestvu lekarstvennykh sredstv, 2011. $15 \mathrm{~s}$.

4. Terekhov A.Yu. Aktual'nye voprosy mezhdunarodno-pravovogo regu-lirovaniya predotvrashcheniya oborota fal'sifitsirovannykh lekarstvennykh sredstv v ramkakh mezhpravitel'stvennykh organizatsii // Evraziiskii yuri-dicheskii zhurnal. 2011. № 4. S. $24-29$.

5. Terekhov A.Yu. Mezhdunarodno-pravovye sredstva predotvrashcheniya oborota fal'sifitsirovannykh lekarstvennykh preparatov. Avtoref. ... kand. yurid. nauk. M., 2011. 23 s.

6. Ushkalova E.A. Problemy fal'sifikatsii lekarstvennykh sredstv: fokus na antimikrobnye preparaty // Klinicheskaya mikrobiologiya i anti-mikrobnaya khimioterapiya. 2005. T.

7. A.A. Rerikht. Aktual'nye problemy meditsinskoi etiki // Filosofiya i kul'tura. - 2010. - № 8. - S. 104-107.

8. O. L. Dubovik, A.A. Rerikht. Transplantatsiya organov, tkanei i kletok v pravovom i kriminologicheskom aspektakh // Pravo i politika. - 2011. - № 12. - S. 104-107.

9. A. R. Shayakhmetova. Obyazannosti storon dogovora vozmezdnogo okazaniya meditsinskikh uslug. // Pravo i politika. - 2011. - № 2.

10. N. M. Dobrynin, A. N. Mitin. Komu vygodno (sui prodest) nakhozhdenie Rossii v VTO? // Pravo i politika. - 2012. - № 9. - S. 104-107.

11. O. V. Zhurkina, I. M. Cherevchina, Yu. L. Belyaeva. Pravovoe osnovanie klassifikatsii meditsinskikh otkhodov // Pravo i politika. - 2012. - № 3. - S. 104-107.

12. Polubinskaya S.V.. Meditsinskoe pravo v sovremennom gosudarstve // Pravo i politika. - 2013. - № 7. S. 104-107. DOI: 10.7256/1811-9018.2013.7.8981

13. K.I. Korobko. Ponyatie, priznaki, elementy dogovora na okazanie meditsinskikh uslug, zaklyuchaemogo sub"'ektami chastnoi meditsinskoi praktiki // Pravo i politika. - 2010. - № 9. 
14. Mal'tsev A.E., Mel'nikov O.V. Standarty v sisteme zdravookhraneniya i sudebnoi meditsine // NB: Rossiiskoe politseiskoe pravo. - 2014. - № 1. - S.135-142. DOI: 10.7256/2306-4218.2014.1.9910. URL: http://e-notabene. $\mathrm{ru} / \mathrm{pm} /$ article_9910.html

15. M.I. Litovkina. Rol' sotsial'nogo gosudarstva $\mathrm{v}$ obespechenii lekarstvennoi bezopasnosti pri realizatsii konstitutsionnogo prava na okhranu zdorov’ya // Pravo i politika. - 2013. - № 1. - S. 104-107. DOI: 10.7256/1811-9018.2013.01.5

16. L. E. Poteryaiko. Rynok donorskoi krovi i ee komponentov kak neobkhodimost' sovershenstvovaniya sistemy meditsinskogo obespecheniya naseleniya // Politika i Obshchestvo. - 2012. - № 8. - S. 104-107.

17. Zholobova G.A.. Problemy pravovogo obespecheniya chastnogo i obshchestvennogo interesov v sfere kommercheskoi farmatsevticheskoi deyatel'nosti v Rossii 1881-1912 gg. // Politika i Obshchestvo. - 2013. - № 10. - S. 104-107. DOI: 10.7256/1812-8696.2013.10.7706

18. E.L. Panova. Medikalizatsiya zdorov'ya: illyuziya, sposobnaya razrushit' cheloveka// Filosofiya i kul'tura. - 2012. - № 8. - S. 104-107.

19. B.I. Almazova. Sovremennye tendentsii pravovogo regulirovaniya meditsinskoi deyatel'nosti // Pravo i politika. -2010 . - № 1 .

20. O.L. Dubovik, A.A. Rerikht. Chelovek i meditsina: pravovye, filosofskie i eticheskie aspekty // Pravo i politika. - 2009. - № 11.

21. I. I. Nagornaya. Predmetnaya kharakteristika meditsinskoi deyatel'nosti kak osnova ee ugolovno-pravovoi okhrany (opyt Rossii, SShA, Frantsii) // Pravo i politika. - 2012. - № 5. - S. 104-107. 7. № 2. S. 167 - 173. 7. Bate R. Fake: The Deadly World of Falsified and Substandard Medi-cines. Washington: AEI Press, 2012. $400 \mathrm{rp}$.

22. Chika A., Bello S.O., Jimoch A.O., Umar M.T. The Menace of Fake Drugs: Consequences, Causes and possible Solutions // Research Journal of Med-ical Sciences. 2011. Vol. 5. Issue 5. P. 258 - 261.

23. Davison M. Pharmaceutical Anti-Counterfeiting Combating the Real Danger from Fake Drugs. New Jersey: Wiley, 2011. $426 \mathrm{rp}$.

24. Wertheimer A., Wang P. (eds.) Counterfeit medicines. Vol. I. Policy, Economics and Countermeasures. Glendale: ILM Publications, 2012. 154 pp.

25. S. Yu. Koblov Pravovaya okhrana izobretenii v sootvetstvii s Soglasheniem po torgovym aspektam prav na intellektual'nuyu sobstvennost' (TRIPS). // Mezhdunarodnoe pravo i mezhdunarodnye organizatsii / International Law and International Organizations. - 2011. - 4. - C. 137-141.

26. O. V. Markova Perspektivy pravovoi zashchity intellektual'noi sobstvennosti i sposoby ukrepleniya ustoichivogo elementa sistemy pravovoi zashchity intellektual'noi sobstvennosti // Politika i Obshchestvo. $-2012 .-6 .-$ C. $101-106$. 